\title{
How do women entrepreneurs use the virtual network Facebook?
}

\section{The impact of gender}

\section{Christina Constantinidis}

\begin{abstract}
This paper examines the views and attitudes of a sample of 228 female entrepreneurs in Belgium towards the virtual social network Facebook. It uses statistical analysis to evaluate the impact of their gendered sector of activity and of their self-perceptions on: how Facebook is perceived as responding to gender-related difficulties; how Facebook is used in terms of objectives and activities; how Facebook supports women's networks; and the outcomes of Facebook for women-owned businesses. The results highlight significant differences according to women's sectors of activity and self-perceptions with regard to how Facebook is perceived and used. They support the idea of an active posture of women entrepreneurs, allowing for action to be taken to deconstruct and counterbalance existing gender dynamics. The paper highlights certain implications for public and private initiatives and underlines the potential of this and other virtual social networking sites for women's entrepreneurship.
\end{abstract}

Keywords: women's entrepreneurship; virtual networks; gender; Facebook

Christina Constantinidis is with the Public Research Centre Henri Tudor, Service Science and Innovation, Research Unit IMAGINE - Innovation Management: People and Organization, 29 avenue John F. Kennedy, L-1855 Luxembourg. E-mail: christina.constantinidis@tudor.lu. She is also an Invited Professor at HEC Management School, University of Liège, Belgium.

Launched in February 2004, Facebook is a global and open social network that allows users to create personal profiles, connect, share information and communicate with each other. To date, Facebook.com is the second most-trafficked website in the world after Google, with over 500 million active users (Facebook, 2010).

Virtual social networks, such as Facebook or LinkedIn, the Internet and other new communication technologies essentially allow users to overcome geographical distance and time constraints for information and interaction purposes (Chen and Wellman, 2009; Schwartz-DuPre, 2006). For entrepreneurs in particular, they provide significant added value in terms of social capital. Indeed, new communication technologies provide entrepreneurs with larger networks and access to previously unattainable resources both geographically and socially, thus enhancing opportunities to connect with clients, suppliers, channel partners and network contacts (Chen and Wellman, 2009; Loane, 2006).

Women increasingly use online communication tools to maintain personal and professional contacts (Weiser, 2000), and are more likely than men to use social network sites (Tufekci, 2008). On Facebook, women tend to be more socially active and to have a greater diversity of network resources available to them than men (Lewis et al, 2008). Some studies present new 
communication technologies as an opportunity for women to counterbalance and overcome the difficulties and barriers that they may face in real-life interactions (Herring, 2001; Knouse and Webb, 2001; SchwartzDuPre, 2006).

Given our interest in the potential of virtual social networks for women entrepreneurs, their networks and their businesses, we here take a gender perspective on women entrepreneurs' involvement in Facebook. In line with the works of Ahl (2004, 2006), de Bruin et al (2007), Ely and Padavic (2007), Kergoat (2000) and others, we understand gender as being different from biological sex and define it as 'socially constructed sex'. We aim to investigate the impact of gender on these women's perceptions of Facebook as responding to difficulties they have encountered in real-life networking; how they use it in terms of objectives and activities; how it may encourage and support networks; and what Facebook brings to women-owned businesses. Our research questions, in particular, focus on the influence of women entrepreneurs' gendered professional environments and self-perceptions. Rather than placing them in a comparative perspective with their male counterparts, we approach them as a diverse group and focus on the contextual differences existing between them.

\section{Literature review}

\section{Women entrepreneurs and networking}

Networking has been recognized as a crucial entrepreneurial activity, for both male and female entrepreneurs, helping them to gather valuable information and advice, to identify opportunities and access critical resources for business creation, maintenance, development and entrepreneurial success (Aldrich et al, 1989; Åndersson and Evensson, 2000; Baines and Wheelock, 1998; Doyle and Young, 2001; Hall and Bennett, 2000; Hampton et al, 2009; Mankelow et al, 2002; Manolova et al, 2006, 2007; Veltz, 2002). The literature on women's entrepreneurship nonetheless highlights the difficulties in terms of networking activities.

Women entrepreneurs seem to encounter barriers in accessing traditionally male-dominated established networks, known as 'old boys' networks' (Aldrich, 1989; Blisson and Rana, 2001; Gamba and Kleiner, 2001; Hamouda et al, 2003; Manolova et al, 2006). By way of explanation for this, the literature evokes their lack of self-confidence, their fear of being discriminated against, or their lack, as they see it, of competence or credibility (Blisson and Rana, 2001; Hampton et al, 2009; Smeltzer and Fann, 1989). Women entrepreneurs also have concerns about the time and effort needed to become familiar with this type of network (Smeltzer and
Fann, 1989; St-Cyr et al, 2001), given the pressures of domestic responsibilities on their schedules (Aldrich, 1989; Blisson and Rana, 2001; Hamouda et al, 2003; Hampton et al, 2009; St-Cyr and Gagnon, 2004). Hampton et al (2009), focusing on women entrepreneurs in a male-dominated sector, in contrast, find that these challenges are relatively easy to overcome, and even suggest that some of the women they surveyed said being a woman constituted an advantage in this respect.

Female entrepreneurs' networks are often presented as less valuable and of lower quality than those of males in terms of size, density, range and strength of ties. This lack of quality is generally accounted for by women's particular approaches to networking. Women entrepreneurs seem to resort to them for social relationships, while men do so for more instrumental advantages (Aldrich, 1989; Belcourt et al, 1991; Buttner, 1993; Fenwick, 2003; Moore, 1990; Moore and Buttner, 1997; St-Cyr et al, 2001). Women tend to have stronger ties in their networks (Carter et al, 2003), in particular with close friends and family. As compared with men, their networks are also smaller and less diverse (Aldrich, 1989; Moore, 1990; Renzulli et al, 2000; Ruef et al, 2003). Finally, women entrepreneurs' networks tend to consist mainly of female contacts (Aldrich, 1989; Aldrich et al, 1989; Åndersson and Evensson, 2000; Cromie and Birley, 1992; Fenwick, 2003; Lambrecht et al, 2003; Manolova et al, 2006; Ruef et al, 2003; Smeltzer and Fann, 1989). Other studies, on the contrary, do not find any distinct traits in terms of networks and networking (Buttner and Rosen, 1988; Cromie and Birley, 1992; Hall and Bennett, 2000; Katz and Williams, 1997). Women entrepreneurs come out as equally aggressive and efficient in their effort to access critical resources through networks (Blisson and Rana, 2001; Hamouda et al, 2003; Katz and Williams, 1997). In the technology sector, women business owners appear to be active networkers in building the large and diverse networks crucial for their activity (Hampton et al, 2009).

\section{Virtual networks and women}

The Internet and other new communication technologies are presented as remedying a good many problems and barriers encountered by women, such as through changing the traditional balance of power and opening up opportunities for less economically, socially and politically powerful groups, including women (Herring, 2001; Schwartz-DuPre, 2006). In particular, use of the Internet may compensate for the invisibility and lack of agency experienced by those who are underrepresented in some professional contexts (Schwartz-DuPre, 2006). Building and maintaining contacts through the Internet is perceived as a solution to their limited access to faceto-face interactions, particularly owing to time and 
location constraints (Knouse and Webb, 2001). The Internet thus works to extend and strengthen their networks geographically and socially (Chen and Wellman, 2009; Knouse and Webb, 2001), and it does so on the basis of common interests, regardless of age, location or any other social barriers present in real life that impede people lacking community (Knouse and Webb, 2001; Schwartz-DuPre, 2006).

Women have mainly used the Internet and other new communication technologies to create and develop virtual communities, within which they can now share experiences, concerns, beliefs and common interests (Herring, 2001; Schwartz-DuPre, 2006). Growing numbers of women venture capitalists, business owners and consumers use the Internet to interact with and support each other, becoming key players in the online landscape (Herring, 2001). Women's groups are created online to offer networking support through providing them, and especially entrepreneurs and executives, with information and lists of contacts (Knouse and Webb, 2001).

Women's connections via the Internet also have positive implications in real life. Women active in male professional environments and/or in competitive professional environments a priori feel disconnected if not in a position of rivalry with each other. By giving them a channel whereby they can share experience and information as well as commitment to a common activity, virtual social networking not only creates a visible and agency-laden community, but also improves their experiences generally (Herring, 2001; Schwartz-DuPre, 2006).

\section{Theoretical framework and research questions}

The use of virtual social networks by women entrepreneurs has scarcely been dealt with in the scientific literature, whether within women's entrepreneurship studies or in the new technological media. Networking websites, however, offer women business owners significant opportunities and advantages in terms of networking and social capital.

The present study focuses on women entrepreneurs' perceptions and use of Facebook. Besides identifying the main trends in virtual social networking, it proposes an analysis in terms of gender, defined as 'socially constructed sex', in line with the works of Ahl (2004, 2006), de Bruin et al (2007), Ely and Padavic (2007), Kergoat (2000) and others. In particular, it explores the influence of the gendered professional environment (Hampton et al, 2009; Constantinidis, 2010) and of women's self-perceptions and positioning (Constantinidis, 2010) in relation to Facebook, their participation in all-female networks on Facebook and the implications for their professional activity. So, rather than a sex-based account of entrepreneurship, it aims to account for contextual differences between groups of women entrepreneurs, seen as representing multiple and diverse realities.

First, starting from the evidence that women entrepreneurs encounter a number of barriers to effective networking, we wonder to what extent they view Facebook as an aid to solving some of these difficulties. We also explore how gender may impact on their perceptions in different contexts.

$R Q 1$. How do women entrepreneurs' perceptions of their gendered sectors of activity and of themselves affect their view of Facebook as supporting their activity?

Second, we explore to what extent women entrepreneurs use Facebook for professional purposes, for private issues and/or for women's entrepreneurship exchange and support. This question relates to the existing debate in the literature about women entrepreneurs' relational versus instrumental objectives in using networks. We also investigate the potential influence of gender.

$R Q 2$. How do women entrepreneurs' perceptions of their gendered sectors of activity and of themselves affect their use of Facebook in terms of initial and achieved objectives and activities?

Third, we wonder to what extent Facebook may serve to foster and support women's business networks. This question stems from the use of virtual tools to build and develop communities of women, in order to gain visibility and to support each other, as underlined in the literature. We investigate the perceptions and participation of women entrepreneurs in all-female networks on Facebook. We also explore the influence of gender.

$R Q 3$. How do women entrepreneurs' perceptions of their gendered sectors of activity and of themselves affect their perceptions of and participation in allfemale networks on Facebook?

Finally, our fourth question refers to the concrete outcomes of women entrepreneurs' social networking on Facebook for their professional activity: whether Facebook provides them with new professional contacts, including clients, suppliers, subcontractors and business partners, also taking account of the localities of these new contacts.

$R Q 4$. How do women entrepreneurs' perceptions of their gendered sectors of activity and of themselves affect the outcome of Facebook in terms of new professional contacts? 


\section{Methods}

The research project took place in Belgium. We used a quantitative methodology in order to answer our different research questions. A questionnaire was developed and administered online to a sample of female entrepreneurs. Descriptive and inferential statistics were used to analyse the data.

\section{Participant sampling}

We gathered a sample of 228 female entrepreneurs for our survey, posted this online and publicized it directly via Facebook using the 'events' application. Our presentation of the event included a brief summary of our objectives, an invitation to participate and a direct Internet link to the survey. The event was visible and accessible to anyone using Facebook and allowed survey participants to make their participation visible to others and to post comments and interact. We posted the information on our personal profile page on Facebook. Via Facebook, we sent an invitation to all our contacts asking them to participate in the survey if they were female entrepreneurs, and/or to diffuse the information to their own contacts by using the 'share' application and/or by posting the invitation on their personal profile page. We also posted this invitation on the personal pages and/or on websites of different women's networks, including FAR, Diane and Jump. Data collection took place over three months spanning May to July 2010. We launched a second call to participate in the survey in mid-July.

\section{Sample description}

The majority of the women entrepreneurs making up our sample are between 30 and 45 years old (57\%). A quarter of them $(28.5 \%)$ are between 46 and 59, while $12.8 \%$ of the women are under 30 . A large majority of women in our sample $(60.9 \%)$ have children under their responsibility. Nearly half the women in the sample are married or in a relationship, with children (46.9\%), and $14 \%$ of the women are single or living on their own with children. With regard to the women without children under their responsibility, $22.3 \%$ are married or in a relationship and $16.8 \%$ are single or living on their own. In terms of education, three-quarters of the female entrepreneurs in our sample $(76.5 \%)$ are highly educated and hold a Bachelor's (38.5\%) or Master's (38\%) degree. These characterictics accord with the general profile of women entrepreneurs found in the literature.

In line with previous studies, a large majority of the women entrepreneurs making up our sample (74.8\%) own businesses in the services $(49.5 \%)$ and retail $(25.3 \%)$ sectors. Among them, $24.2 \%$ provide businessto-business services and $25.3 \%$ are specialized in
Table 1. Sectors of activity of women-owned businesses.

\begin{tabular}{lcc}
\hline Sectors & Frequency & Percentage \\
Industry/construction & 8 & 4.4 \\
Commerce/retail & 46 & 25.3 \\
Professionals & 18 & 9.9 \\
B-to-B services & 44 & 24.2 \\
B-to-C services & 46 & 25.3 \\
Other & 20 & 10.9 \\
Total & 182 & 100.0 \\
\hline
\end{tabular}

Note: 46 women did not answer the question.

business-to-consumer services. Only $4.4 \%$ of the women in our sample own ventures in industry and construction (see Table 1).

The women entrepreneurs making up our sample own businesses created between 1971 and 2010 and with an average of six years' existence. Nearly three-quarters of the women of our sample have young businesses, created up to five years ago $(73.5 \%)$, a large proportion of which are less than three years old (44.6\%). In terms of size, a large majority of the women in our sample have no employees $(61.2 \%)$; close to one-third have between one and nine employees $(30.3 \%)$, while only 14 women in our sample own enterprises with 10 to 300 employees. Over half of our sample own non-incorporated ventures $(50.3 \%)$. Among those who own incorporated companies, $21.8 \%$ own a limited liability company. Only $5.6 \%$ run public limited companies. Most of the women entrepreneurs in our sample have created their own businesses, whereas 16 have taken over a family business or an external company. More than three-quarters of the sample $(78.6 \%)$ run their businesses as their principal activity, with $18.5 \%$ of women running them as a secondary activity. Finally, $2.9 \%$ of the women in our sample are assisting spouses.

\section{Measures}

\section{Independent variables}

Studies mostly have a priori assumptions about the feminine or masculine composition of activity sectors. Instead of taking the sectoral sex composition for granted, we asked women entrepreneurs how they perceived the sex composition of their own sectors. The results offer a different picture from what might be expected. As Table 2 shows, approximately one-third of the female entrepreneurs in our sample (35.4\%) perceive their sector as mainly feminine, one-third consider that there is an equal proportion of men and women (34.8\%), and almost one-third perceive their sector to be mainly masculine (29.8\% of women). The sex composition of the sector of activity is a categorical variable with three response choices. 
Table 2. Gendered sectors of activity of women entrepreneurs.

\begin{tabular}{lcc}
\hline $\begin{array}{l}\text { Sex composition of } \\
\text { sectors of activity }\end{array}$ & Frequency & Percentage \\
Majority feminine & 64 & \\
Majority masculine & 54 & 35.4 \\
Mixed & 63 & 29.8 \\
Total & 181 & 34.8 \\
\hline
\end{tabular}

Note: 47 women did not answer the question.

The gendered self-perceptions of women entrepreneurs were evaluated by the extent to which women entrepreneurs identify themselves with the group of women entrepreneurs in general or, on the contrary, differentiate themselves from this group. We used two statements relating to self-categorization taken from Ellemers et al (1999) and one statement evaluating the perception of prototypicality with the other group members taken from Ashmore et al (2004). Items were worded to indicate 'women entrepreneurs' as the social group of interest. In terms of the reliability of the scale, we report a Cronbach's alpha coefficient of 0.70 , hence acceptable. A Likert-type scale is generally considered as having an acceptable level of internal consistency when Cronbach's alpha $\geq 0.70$. We asked women entrepreneurs to indicate the degree to which they agreed or disagreed with the statements using a 4-point Likert-type scale ranging from 1 (totally disagree) to 4 (totally agree). As our sample is relatively important, we consider the Likert-type scale as a numerical variable. The identification with the group of women entrepreneurs is therefore measured by the three-item Likert-type scale ranging from 3 to 12 . We used the sums of the scores obtained for the three items, as this improves the fidelity of results.

\section{Dependent variables}

We used two statements to study to what extent Facebook was perceived as an adapted tool for women, and two other statements were related to the perceived difficulties in terms of networking. We asked women entrepreneurs to indicate the degree to which they agreed or disagreed with each statement using a 4-point Likert-type scale.

To study women entrepreneurs' initial and fulfilled objectives in using Facebook, we asked the following questions: 'Which were your objectives when you decided to subscribe to Facebook?' and 'Now that you've used Facebook, to what extent, would you say, did it enable you to fulfil the following objectives?' We proposed a list of objectives, including three related to their business, three related to women's entrepreneurship and three related to their private life. Cronbach's alpha coefficients range between 0.70 and 0.90 . Women entrepreneurs were asked to indicate the degree of importance of each objective using a 4-point Likert-type scale. The degrees of importance of objectives related to the business, to women's entrepreneurship and to their private life are each measured by a three-item Likerttype scale ranging from 3 to 12 . We used the sums of the scores obtained for the individual items.

We also explored the activities undertaken on Facebook in practice. The question was: 'In practice, what activities do you use Facebook for?' Different activities were listed. Women entrepreneurs were asked to indicate to what extent they used Facebook for each activity using a 4-point Likert-type scale. The scores obtained for four items were summed to evaluate the degree to which women entrepreneurs used Facebook for professional activities (Cronbach's alpha $=0.84$ ). The degree to which women entrepreneurs use Facebook for professional activities is therefore measured by a three-item Likert-type scale ranging from 4 to 16. The five remaining items were evaluated individually.

To study women entrepreneurs' participation in allfemale networks on Facebook, we used questions with response choices of either 'yes' or 'no' on their participation in different women's networks on Facebook. We also asked whether they participated in one or more mixed networks (yes/no). In addition to this factual information, four statements were used to explore their perceptions of male, mixed and female networks. We asked women entrepreneurs to indicate the degree to which they agreed or disagreed with the statements using a 4-point Likert-type scale.

Finally, to study the outcomes of using Facebook for women entrepreneurs' professional activity, we used questions with response choices on the following topics: whether they had gained new suppliers, subcontractors or business partners via Facebook in 2009; whether they had gained new clients via Facebook in 2009 (yes/no); the locality of their new suppliers, subcontractors or business partners; the locality of their new clients (at the provincial/regional/national or international level); and the number of these new clients (less than $5 / 5$ to $10 / 10$ to $20 /$ more than 20 ). These were categorical variables with response choices.

\section{Analyses}

Descriptive statistics were calculated on factual information about the context of sign-ups to Facebook, on data on the participation in all-female and mixed networks on Facebook and on data on the outcomes of Facebook in terms of new professional contacts. Analysis of covariance (ANCOVA) was conducted comparing 
women entrepreneurs in male, female or mixed sectors with the outcome measure of the scales and relevant items, while controlling for the effect of gendered selfperception. When significant results were obtained, the Newman-Keuls post hoc test was used in order to understand better the reasons that made ANCOVA reject the null hypothesis.

Correlation matrix analyses were run to analyse the correlations between gendered self-perception and the other continuous variables related to the perceptions of Facebook as a useful tool for women, their perceived difficulties as women, their perceptions about all-female and mixed networks, and the initial and fulfilled objectives as well as the activities undertaken on Facebook. Analysis of variance (ANOVA) was conducted comparing women participating in female (or mixed) networks on Facebook with those who did not, in terms of gendered self-perception.

As considered appropriate, Pearson chi-square analyses were conducted comparing women entrepreneurs in male, female or mixed sectors on a number of categorical items. Cramer's V post-test was used to determine strengths of association after Pearson chisquare determined significance. Two-way ANOVA analyses were conducted complementarily to control for the effect of gendered self-perception, with NewmanKeuls post hoc tests used when appropriate to understand better the observed effects of interaction. Statistica 9.1 was used for all analysis.

\section{Results}

\section{Descriptive data}

A large majority of the women entrepreneurs in our sample had signed up for Facebook over one year ago $(80.8 \%)$. Over half of our sample $(52.2 \%)$ initially signed up for Facebook in both professional and private contexts. The others initially signed up in a strictly private context (39.7\%) (see Table 3).

Table 4 shows the statistics on the frequency of connection to Facebook. Over half of the women entrepreneurs in our sample connect to it every day $(56.5 \%)$; approximately one-quarter do so at least

Table 3. Initial context of sign-up for Facebook.

\begin{tabular}{lcc}
\hline Initial context of & Frequency & Percentage \\
sign-up for Facebook & & \\
Strictly private & 89 & 39.7 \\
Strictly professional & 18 & 8.1 \\
Both private and professional & 117 & 52.2 \\
Total & 224 & 100.0 \\
\hline
\end{tabular}

Note: 4 women did not answer the question.

\section{Table 4. Frequency of connection to Facebook.}

\begin{tabular}{lcc}
\hline Frequency of connection & Frequency & Percentage \\
Less than once a week & 34 & 16.8 \\
Not every day, but several & & \\
$\quad$ times a week & 54 & 26.7 \\
Every day & 114 & 56.5 \\
Total & 202 & 100.0 \\
\hline
\end{tabular}

Note: 26 women did not answer the question.

several times per week (26.7\%); and $16.8 \%$ connect to it less than once a week.

Of the women entrepreneurs in our sample, $40.4 \%$ (92 women out of 228) report participation in another virtual network in addition to Facebook; they participate in LinkedIn (76.1\%), Viadeo (54.3\%), Twitter (17.4\%) and/or another virtual network such as Plaxo, Foursquare, etc $(14.1 \%)$.

Descriptive data are presented in Table 5 regarding the perceived gender-related difficulties in networking, the perception of Facebook as a useful tool for women, the initial and fulfilled objectives and activities on Facebook, plus perceptions of women's and mixed networks.

Descriptive data on professional contacts made through Facebook in 2009 (see Table 6) reveal that onethird of the women entrepreneurs in our sample (33.5\%) gained new suppliers, business partners or subcontractors at the provincial $(9.9 \%)$, regional $(5.5 \%)$, national $(7.1 \%)$ or international $(11 \%)$ levels.

As Table 7 shows, nearly half of the women entrepreneurs in our sample $(46.4 \%)$ gained new clients through the use of Facebook in 2009 at provincial (18.5\%), regional $(6.5 \%)$, national $(13 \%)$ or international $(8.2 \%)$ level. For the most part, they gained up to 10 new clients (Table 8).

Descriptive data on participation in mixed and allfemale networks on Facebook show that $18.6 \%$ of the women entrepreneurs in our sample participate in networks identified as mixed in terms of sex composition. In contrast, $78.1 \%$ report participation in a women's network on Facebook. These women entrepreneurs are members of FAR (36\%), Diane (16.9\%), Jump $(11.8 \%)$ and/or another women's network (19.7\%) such as FCEM, Perle, Meridienne, Club L International, $A F F A$ and other formal or informal female networks (see Figure 1).

\section{Analytical results}

Perceptions about Facebook and perceived difficulties in terms of networking. The ANCOVA analysis does not reveal a statistically significant effect of the sex composition of the activity sector either on the women entrepreneurs' perceptions of Facebook as a useful tool 
Table 5. Characteristics of women entrepreneurs.

\begin{tabular}{|c|c|c|}
\hline Variable & Mean & SD \\
\hline Gendered self-perception ${ }^{\mathrm{a}}$ & 7.79 & 1.79 \\
\hline $\begin{array}{l}\text { Perceptions of Facebook as a useful tool for women } \\
\text { 'Facebook is a tool particularly adapted for women' } \\
\text { 'Facebook allows for conciliating the networking activity with family life' } \\
\text { 'As a woman, I feel difficulty in networking with men' } \\
\text { 'I find it difficult to be a woman in a mostly masculine group' }\end{array}$ & $\begin{array}{l}2.28 \\
2.81 \\
1.74 \\
2.04\end{array}$ & $\begin{array}{l}0.87 \\
0.80 \\
0.74 \\
0.87\end{array}$ \\
\hline $\begin{array}{l}\text { Initial and fulfilled objectives on Facebook } \\
\text { Initial objectives related to professional concerns } \\
\text { Initial objectives related to women's entrepreneurship support } \\
\text { Initial objectives related to private life issues } \\
\text { Fulfilled objectives related to professional concerns } \\
\text { Fulfilled objectives related to women's entrepreneurship support } \\
\text { Fulfilled objectives related to private life issues }\end{array}$ & $\begin{array}{l}7.52 \\
6.48 \\
8.80 \\
7.56 \\
7.14 \\
9.31\end{array}$ & $\begin{array}{l}3.00 \\
2.48 \\
1.99 \\
2.07 \\
2.33 \\
2.07\end{array}$ \\
\hline $\begin{array}{l}\text { Activities on Facebook } \\
\text { Professional activities } \\
\text { 'I initiate or maintain private contacts (friends, family...)' } \\
\text { 'I share my mood, my feelings, my difficulties' } \\
\text { 'I publish initiatives from other entrepreneurs' } \\
\text { 'I make women entrepreneurs and their initiatives known' } \\
\text { 'I play games, participate in competitions, have fun' }\end{array}$ & $\begin{array}{l}10.02 \\
3.07 \\
1.96 \\
2.46 \\
2.29 \\
1.48\end{array}$ & $\begin{array}{l}3.20 \\
0.67 \\
0.87 \\
0.90 \\
0.87 \\
0.68\end{array}$ \\
\hline $\begin{array}{l}\text { Perceptions about mixed and women's networks } \\
\text { 'The female business networks are not useful at all' } \\
\text { 'To make business, it is more interesting to participate in majority male networks' } \\
\text { 'The exclusively female networks offer me more than masculine or mixed networks' } \\
\text { 'Facebook offers an important added-value for female networks' }\end{array}$ & $\begin{array}{l}3.29 \\
3.04 \\
2.01 \\
2.43\end{array}$ & $\begin{array}{l}0.73 \\
0.67 \\
0.83 \\
0.80\end{array}$ \\
\hline
\end{tabular}

Note: $\mathrm{N}=112$ (women who answered all questions). ${ }^{\mathrm{a} T h r e e-i t e m ~ L i k e r t-t y p e ~ s c a l e ~ r a n g i n g ~ f r o m ~} 3$ to $12 ;{ }^{b}$ Four-item Likert-type scale ranging from 4 to 16 .

\begin{tabular}{lcc}
$\begin{array}{l}\text { Table 6. New suppliers, business partners or subcontrac- } \\
\text { tors via Facebook in 2009. }\end{array}$ & \\
\hline New suppliers, business & Frequency & Percentage \\
partners or subcontractors & & \\
No & 121 & 66.5 \\
Yes & 61 & 33.5 \\
Provincial level & 18 & 9.9 \\
Regional level & 10 & 5.5 \\
National level & 13 & 7.1 \\
International level & 20 & 11.0 \\
Total & 182 & 100.0 \\
\hline
\end{tabular}

Note: 46 women did not answer the question.

\begin{tabular}{lcc}
\hline \multicolumn{3}{l}{ Table 7. New clients via Facebook in 2009. } \\
\hline New clients & Frequency & Percentage \\
No & 98 & 53.6 \\
Yes & 85 & 46.4 \\
Provincial level & 34 & 18.6 \\
Regional level & 12 & 6.5 \\
National level & 24 & 13.1 \\
International level & 15 & 8.2 \\
Total & 183 & 100.0 \\
\hline
\end{tabular}

Note: 45 women did not answer the question.

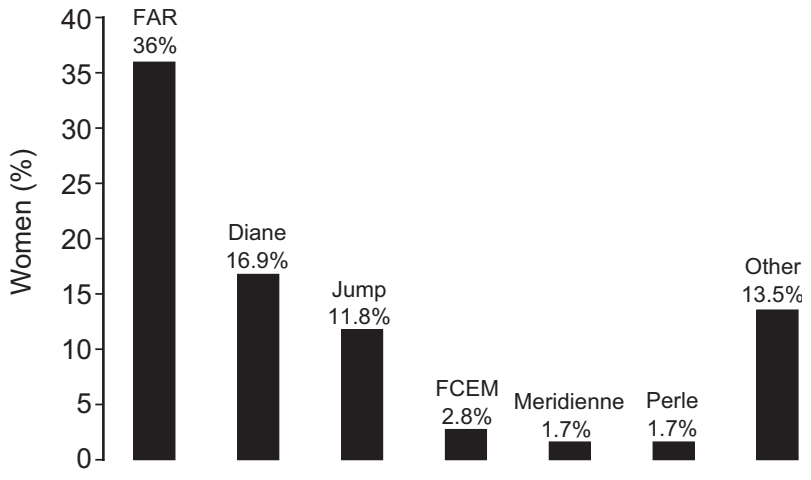

Figure 1. Participation in a women's network on Facebook.

\begin{tabular}{lcc}
\multicolumn{3}{l}{ Table 8. Number of new clients via Facebook in $\mathbf{2 0 0 9 .}$} \\
\hline Number of new clients & Frequency & Percentage \\
$<5$ new clients & 45 & 53.6 \\
$5-10$ new clients & 20 & 46.4 \\
$10-20$ new clients & 6 & 18.6 \\
$>20$ new clients & 14 & 6.5 \\
Total (of women who & 85 & 100.0 \\
gained new clients) & & \\
\hline
\end{tabular}

Note: 45 women did not answer the question; 98 women did not gain any clients via Facebook in 2009. 
How do women entrepreneurs use Facebook?

Table 9. Gendered self-perception and perceptions about Facebook.

\begin{tabular}{|c|c|c|c|c|}
\hline & FB adapted to women & $\begin{array}{c}\text { FB useful for } \\
\text { work-life balance }\end{array}$ & $\begin{array}{l}\text { Difficulties in network- } \\
\text { ing with men }\end{array}$ & $\begin{array}{l}\text { Difficulties in being a } \\
\text { woman in a male group }\end{array}$ \\
\hline Gendered self-perception & $\begin{array}{c}0.1362 \\
p=0.152\end{array}$ & $\begin{array}{c}0.3736 \\
p=0.000\end{array}$ & $\begin{array}{c}0.2213 \\
p=0.019\end{array}$ & $\begin{array}{c}0.2304 \\
p=0.015\end{array}$ \\
\hline
\end{tabular}

Note: Significant correlations (in bold) at $p<0.05 . \mathrm{N}=112$.

Table 10. Gendered self-perception and objectives on Facebook.

\begin{tabular}{|c|c|c|c|c|c|c|}
\hline & $\begin{array}{l}\text { Business } \\
\text { objectives } \\
\text { (initial) }\end{array}$ & $\begin{array}{c}\text { Women's } \\
\text { entrepreneurship } \\
\text { (initial) }\end{array}$ & $\begin{array}{l}\text { Private } \\
\text { objectives } \\
\text { (initial) }\end{array}$ & $\begin{array}{l}\text { Business } \\
\text { objectives } \\
\text { (fulfilled) }\end{array}$ & $\begin{array}{c}\text { Women's } \\
\text { entrepreneurship } \\
\text { (fulfilled) }\end{array}$ & $\begin{array}{c}\text { Private } \\
\text { objectives } \\
\text { (fulfilled) }\end{array}$ \\
\hline $\begin{array}{l}\text { Gendered } \\
\text { self-perception }\end{array}$ & $\begin{array}{c}0.0392 \\
p=0.681\end{array}$ & $\begin{array}{c}0.2793 \\
p=0.003\end{array}$ & $\begin{array}{c}0.1141 \\
p=0.231\end{array}$ & $\begin{array}{c}0.2031 \\
p=0.032\end{array}$ & $\begin{array}{c}0.2982 \\
p=0.001\end{array}$ & $\begin{array}{c}0.1082 \\
p=0.256\end{array}$ \\
\hline
\end{tabular}

Note: Significant correlations (in bold) at $p<0.05 . \mathrm{N}=112$.

\begin{tabular}{|c|c|c|c|c|c|c|}
\hline & $\begin{array}{c}\text { Professional } \\
\text { activities }\end{array}$ & Private contacts & Share mood & $\begin{array}{l}\text { Initiatives } \\
\text { of others }\end{array}$ & $\begin{array}{l}\text { Initiatives of } \\
\text { women }\end{array}$ & Have fun \\
\hline $\begin{array}{l}\text { Gendered } \\
\text { self-perception }\end{array}$ & $\begin{array}{c}0.0038 \\
p=0.968\end{array}$ & $\begin{array}{c}0.0355 \\
p=0.710\end{array}$ & $\begin{array}{c}0.0628 \\
p=0.510\end{array}$ & $\begin{array}{c}0.1393 \\
p=0.143\end{array}$ & $\begin{array}{c}0.3079 \\
p=0.001\end{array}$ & $\begin{array}{l}-0.1280 \\
p=0.179\end{array}$ \\
\hline
\end{tabular}

Note: Significant correlations (in bold) at $p<0.05 . \mathrm{N}=112$.

for them, or on their perceived difficulties as women in terms of networking. Indeed, our results do not show any significant difference with regard to networking with men in male, female or mixed sectors, $\mathrm{F}(2,107)=$ $0.13, p>0.05$. The same can be said concerning their perceptions as women in a mainly masculine group, $\mathrm{F}(2,107)=0.27, \mathrm{p}>0.05$, as Facebook as a tool particularly adapted to women, $\mathrm{F}(2,107)=0.66, \mathrm{p}>0.05$, and as a useful tool enabling them to reconcile networking activity with family life, $\mathrm{F}(2,107)=0.75, \mathrm{p}>0.05$.

However, the ANCOVA analysis reveals significant and positive relationships between gendered selfperception and (respectively) the perceived difficulties in networking with men, $\mathrm{F}(2,107)=4.66, p<0.05$, the perceived difficulties in being a woman in a mainly masculine group, $\mathrm{F}(2,107)=6.40, p<0.05$, and the perception of Facebook as a useful tool for reconciling networking activity with family life, $\mathrm{F}(2,107)=16.22$, $p<0.05$. The correlation matrix shows that the linear relationships between gendered self-perception and (respectively) the perceived difficulties in networking with men and the perceived difficulties in being a woman in a mainly masculine group are relatively weak ( $\rho=0.22$ and $\rho=0.23, p<0.05$ respectively). The relationship between gendered self-perception and the perception of Facebook as a useful tool for reconciling networking activity with family life is stronger, even if still moderate $(\rho=0.37, p<0.05$; see Table 9$)$.
Initial and fulfilled objectives and activities on Facebook. The ANCOVA analysis does not reveal a statistically significant effect of the sex composition of the activity sector on the types of objectives of women entrepreneurs when using Facebook initially, or on the fulfilled objectives or activities undertaken on Facebook. Indeed, our results do not show a significant difference between women in male, female or mixed sectors in terms of initial objectives related to professional concerns, $\mathrm{F}(2,107)=0.05, p>0.05$, women's entrepreneurship support, $\mathrm{F}(2,107)=0.23, p>0.05$, or private life issues, $\mathrm{F}(2,107)=0.59, p>0.05$. Neither do they reveal a significant difference between women in the different sectors (male, female, mixed) regarding the fulfilled objectives related to professional concerns, $\mathrm{F}(2,107)=0.41, p>0.05$, women's entrepreneurship support, $\mathrm{F}(2,107)=1.56, p>0.05$, or private life issues, $\mathrm{F}(2,107)=0.34, p>0.05$. Finally, the findings do not indicate a significant difference between women in the different sectors (male, female, mixed) in terms of the types of activities undertaken on Facebook.

However, the ANCOVA analysis reveals significant and positive relationships between gendered selfperception and (respectively) the extent to which women entrepreneurs have initial objectives related to women's entrepreneurship support, $\mathrm{F}(2,107)=9.18, p<0.05$, the extent to which these objectives related to women's entrepreneurship support are fulfilled, $F(2,107)=9.67$, 
Table 12. Comparison of gendered self-perception of women in and not in mixed networks.

\begin{tabular}{lcccc}
\hline \multicolumn{5}{c}{ Women participating in mixed networks } \\
& $\begin{array}{c}\text { Yes, M (SD) } \\
(\mathbf{n}=\mathbf{3 9})\end{array}$ & $\begin{array}{c}\text { No, M (SD) } \\
(\mathbf{n}=\mathbf{1 0 8})\end{array}$ & $\mathbf{F}(\mathbf{1}, \mathbf{1 4 5 )}$ & $\boldsymbol{p}$ \\
Gendered & $7.95(1.96)$ & $7.55(1.87)$ & 1.297 & 0.256 \\
self-perception & & & & \\
\hline
\end{tabular}

Note: $\mathrm{N}=147$ (women who answered both questions). $\mathrm{M}=$ mean; $\mathrm{SD}=$ standard deviation

Table 13. Comparison of gendered self-perception of women in and not in female networks.

\begin{tabular}{lcccc}
\hline \multicolumn{5}{c}{ Women participating in female networks } \\
& $\begin{array}{l}\text { Yes, } \mathbf{M}(\mathrm{SD}) \\
(\mathbf{n}=\mathbf{8 6})\end{array}$ & $\begin{array}{c}\text { No, } \mathbf{M}(\mathrm{SD}) \\
\mathbf{( n = 6 7 )}\end{array}$ & $\mathbf{F}(\mathbf{1}, \mathbf{1 5 1 )})$ & $\boldsymbol{p}$ \\
Gendered & $8.21(1.60)$ & $6.99(2.11)$ & 16.672 & $\mathbf{0 . 0 0 0}$ \\
self-perception & & & & \\
\hline
\end{tabular}

Note: Significant correlations (in bold) at $p<0.05 . \mathrm{N}=153$ (women who answered both questions). $\mathrm{M}=$ mean; $\mathrm{SD}=$ standard deviation.

$p<0.05$, the extent to which objectives related to professional issues are fulfilled, $\mathrm{F}(2,107)=4.16, p<$ 0.05 , and the extent to which women entrepreneurs use Facebook to make known initiatives from other women entrepreneurs, $\mathrm{F}(2,107)=9.95, p<0.05$. The correlation matrix shows that the linear relationship between gendered self-perception and the extent to which objectives related to professional issues are fulfilled is relatively weak $(\rho=0.20, p<0.05)$. The relationships between gendered self-perception and variables linked to women's entrepreneurship support (initial and fulfilled objectives as well as activities on Facebook) are stronger, even if still moderate $(\rho=0.28, \rho=0.30$ and $\rho$ $=0.31$ respectively, $p<0.05)($ see Tables 10 and 11$)$.

Participation in mixed and all-female networks on Facebook. We did not find any significant difference concerning participation in mixed or all-female networks on Facebook for women entrepreneurs in male, female or mixed sectors of activity. Our results show that female entrepreneurs who participate in all-female networks on Facebook identify more strongly with the group of women entrepreneurs than those who do not ( $p$ $<0.05)$. We did not find a significant difference in terms of gendered self-perception between women who participate in mixed networks compared with those who do not. These results are presented in Tables 12 and 13 and Figure 2.

In addition to factual data, we collected information about the perceptions of women entrepreneurs about masculine, mixed and all-female networks.

The ANCOVA analysis does not reveal a statistically

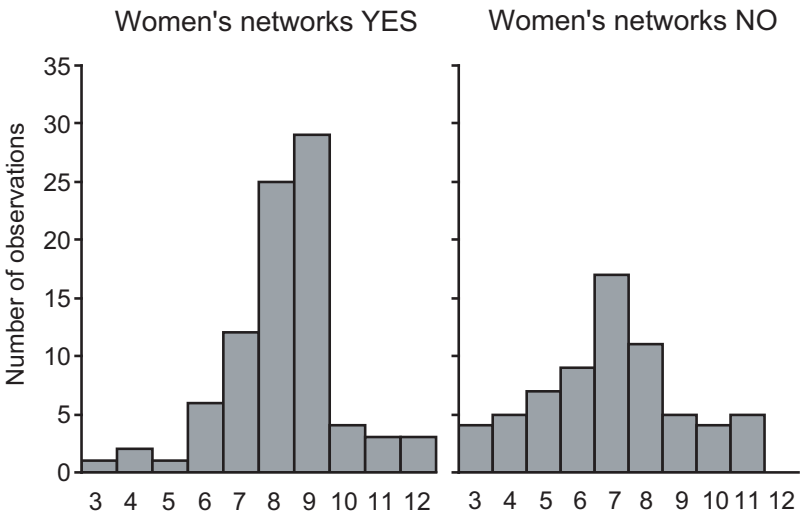

Figure 2. Comparison of gendered self-perception of women in and not in female networks.

significant effect of the sector sex composition on (respectively) the extent to which women consider female business networks as not being useful (reverse coding), $\mathrm{F}(2,107)=1.0, p>0.05$, the extent to which they consider that participating in majority male networks is more interesting for business purposes, $\mathrm{F}(2,107)=0.87, p>0.05$, the extent to which women consider that female networks are more valuable than masculine or mixed networks, $\mathrm{F}(2,107)=0.32, p>0.05$, and the extent to which they perceive Facebook as offering important added value for female networks, $\mathrm{F}(2,107)=0.01, p>0.05$.

However, the ANCOVA analysis reveals significant and positive relationships between gendered selfperception and (respectively) the non-consideration of female networks as not being useful (reverse coding), $\mathrm{F}(2,107)=14.34, p<0.05$, the perception of female networks as being more valuable than masculine or mixed ones, $\mathrm{F}(2,107)=13.89, p<0.05$, and the perception of Facebook as offering an important added value for female networks, $\mathrm{F}(2,107)=8.66, p<0.05$.

The correlation matrix (Table 14) shows that the linear relationships between gendered self-perception and (respectively) the non-consideration of female networks as not being useful, the perception of female networks as more valuable than mixed or masculine

Table 14. Gendered self-perception and perceptions about male, mixed and female networks.

\begin{tabular}{lcccc}
\hline & $\begin{array}{c}\text { Female } \\
\text { networks not networks } \\
\text { not useful } \\
\text { at alla }\end{array}$ & $\begin{array}{c}\text { Male } \\
\text { more } \\
\text { interesting }\end{array}$ & $\begin{array}{c}\text { Female } \\
\text { networks } \\
\text { more } \\
\text { valuable }\end{array}$ & $\begin{array}{c}\text { Facebook } \\
\text { valuable } \\
\text { for female } \\
\text { networks }\end{array}$ \\
$\begin{array}{l}\text { Gendered } \\
\text { self-perception }\end{array}$ & $\mathbf{0 . 3 3 0 5}$ & -0.1210 & $\mathbf{0 . 3 3 3 1}$ & $\mathbf{0 . 2 8 3 6}$ \\
& $\mathbf{p}=0.000$ & $p=0.204$ & $\boldsymbol{p}=\mathbf{0 . 0 0 0}$ & $\boldsymbol{p}=\mathbf{0 . 0 0 2}$
\end{tabular}

Note: Significant correlations (in bold) at $p<0.05 . \mathrm{N}=112$. aReverse coding. 
Table 15. New clients via Facebook in masculine, feminine or mixed sectors.

\begin{tabular}{|c|c|c|c|c|c|c|}
\hline & \multicolumn{6}{|c|}{ New clients via Facebook in 2009} \\
\hline & $\begin{array}{l}\text { Yes }(n=81), \% \\
\text { (frequency) }\end{array}$ & $\begin{array}{c}\text { No }(n=93), \% \\
\text { (frequency) }\end{array}$ & Total & Chi-squared & dl & $p$ \\
\hline Mostly feminine sectors & $61.9(39)$ & $38.1(24)$ & 63 & 9.894509 & $\mathrm{dl}=2$ & $p=0.007$ \\
\hline Mostly masculine sectors & $34.0(17)$ & $66.0(33)$ & 50 & & & \\
\hline Mixed sectors in terms of sex & $41.0(25)$ & $59.0(36)$ & 61 & & & \\
\hline
\end{tabular}

Note: Significant correlations (in bold) at $p<0.05 . \mathrm{N}=174$ (women who answered both questions).

networks, and the perception of Facebook as offering an important added value to female networks are all moderately strong $(\rho=0.33, \rho=0.33$ and $\rho=0.28$ respectively, $p<0.05)$.

The outcome of Facebook in terms of new professional contacts. When comparing the fact of gaining new clients via Facebook among women in masculine, feminine or mixed sectors of activity, our results show statistically significant differences $(\mathrm{p}<0.05)$ - see Table 15. Concerning the strength of the relationship,

Cramer's V $=0.24$. Women entrepreneurs in largely feminine sectors gained new clients via Facebook in greater measure than women in largely masculine or mixed sectors (see Figure 3).

Two-way ANOVA analyses were conducted to control for the effect of gendered self-perception. Our results do not show any statistically significant difference in terms of gendered self-perception between women who gained new clients via Facebook and women who did not, $\mathrm{F}(1,143)=0.09, p>0.05$. No interaction effect was revealed either, $\mathrm{F}(2,143)=2.67, p>0.05$.

Concerning the comparison between women in masculine, feminine or mixed sectors in terms of gaining new suppliers, subcontractors or business partners via Facebook, our results do not reveal any significant differences $(p>0.05)$. Nor do they show any difference in terms of gendered self-perception between women who gained new suppliers, business partners or subcontractors via Facebook and women who did not, $\mathrm{F}(1,143)=0.66, p>0.05$. No interaction effect was revealed either, $\mathrm{F}(2,143)=0.39, p>0.05$.



Figure 3. New clients via Facebook in masculine, feminine and mixed sectors.

\section{Discussion}

In answer to our first question, our findings highlight that the women who perceive themselves as belonging to the group of women entrepreneurs also to a larger extent perceive gender-related difficulties in terms of networking. These findings are consistent with the literature about difficulties encountered by women entrepreneurs in terms of networking (Smeltzer and Fann, 1989; Blisson and Rana, 2001; Hampton et al, 2009). However, difficulties in terms of networking are not reported by all women, but rather depend on their self-positioning as entrepreneurs in terms of gender. Attention must be paid to the fact that considering oneself part of the group of women entrepreneurs increases the perceived gender-related difficulties in terms of networking, while differentiating oneself from other women entrepreneurs decreases these difficulties. This actually questions the meaning and value of 'being a woman' in entrepreneurship and the necessity of or utility in adopting the dominant group behaviours. Lewis (2006) highlights the adoption of masculine behaviours by women in environments characterized by a male culture, which enables them not to be considered as 'the other' and stigmatized. In parallel, our results also show that those women who perceive themselves as 'women' entrepreneurs also to a larger extent perceive Facebook as a useful tool reconciling networking activity and family life. In accordance with the findings of the literature (Knouse and Webb, 2001), Facebook appears to be a solution to some of their gender-related difficulties, allowing for greater balance between networking and family life.

Our second question focused on the use of Facebook in terms of initial and achieved objectives and activities. First of all, our data do not support the statement that women entrepreneurs use networks mainly for relational and not for instrumental purposes (Aldrich, 1989; Moore, 1990; Belcourt et al, 1991; Buttner, 1993; Moore and Buttner, 1997; St-Cyr et al, 2001; Fenwick, 2003). Female entrepreneurs use the virtual social network Facebook for a variety of purposes, and the average scores obtained are similar for all types of objectives and activities. Our analyses reveal that those 
women entrepreneurs who perceive themselves as 'women' entrepreneurs also to a larger extent use Facebook for objectives and activities relating to women's entrepreneurship support. In terms of objectives, when using Facebook, they consider it important to share advice and experiences with other self-employed women, to make women's entrepreneurship known and to meet other women entrepreneurs. In terms of activities, they often make women entrepreneurs and their initiatives known via Facebook. These results can be read in light of the emergence and development of women's communities, in particular of women executives and entrepreneurs, on virtual social networking sites (Herring, 2001; Knouse and Webb, 2001; Schwartz-DuPre, 2006).

Our third question focused on how women entrepreneurs' gendered sectors and gendered self-perceptions affected their perceptions of and participation in women's networks on Facebook. Our findings reveal that women entrepreneurs who participate in all-female networks have higher scores in gendered self-perception than those who do not. They also more frequently perceive these women's networks in more positive terms. In particular, they tend to think that female networks offer them more than male or mixed networks; that Facebook offers important added value for female networks; and that female business networks are useful. These data are consistent with our previous results about the objectives and activities undertaken on Facebook to support women's entrepreneurship. Through women's virtual networks, these women can share their experiences, concerns, beliefs and common interests (Herring, 2001; Schwartz-DuPre, 2006; Hampton et al, 2009).

Our fourth question focused on how women entrepreneurs' gendered sectors and gendered self-perceptions affected the outcome of Facebook in terms of new professional contacts. Our findings highlight the value of Facebook for many women-owned businesses. Indeed, nearly half of them gained new clients through Facebook, and one-third gained new suppliers, business partners or subcontractors via Facebook. These new contacts were situated at both local and international level. Our analyses reveal significant differences between women in male, female and mixed sectors in terms of new clients gained through Facebook. Significantly larger numbers of women in female sectors of activity have gained clients via Facebook, compared with women in male or mixed sectors. One possible explanation for this is that Facebook may be more adapted to establishing commercial relationships in some sectors of activity where women are in the majority. Some types of products and services may be more suitable than others for online contacts with potential or actual clients. Hence virtual networking seems to open up new opportunities and ways of doing business for women entrepreneurs, who can use it to target markets, publicize their products and services, and establish, maintain and develop relations with new or existing customers.

\section{Limitations}

There may be bias related to the purposive sampling method. The sample was non-random and focused on those women entrepreneurs who used Facebook. Also, it is likely that those who responded were going to be more positive in their answers than others.

Future research could compare users with non-users with regard to their perceptions of Facebook and other virtual social networks. It would be interesting to explore to what extent they see the non-use of Facebook as affecting their business.

\section{Conclusions}

Our study focused on women entrepreneurs' perceptions and use of the virtual social network Facebook. We aimed to investigate the impact of gender on how Facebook is perceived as responding to gender-related difficulties; how it is used in terms of objectives and activities; how it may encourage and support women's networks; and how it benefits women-owned businesses. We undertook a gender analysis, defining gender as 'socially constructed sex', which in particular highlighted the influence of the sectors' sex composition and the gendered self-perceptions of women entrepreneurs.

Our findings highlight the diversity of women's entrepreneurship, representing multiple realities. In particular, while we acknowledge the difficulties perceived and lived by some women, we underline that they do not apply indifferently to all female entrepreneurs. There are differences according to the sectors of activity or to their self-positioning. Therefore our results support the idea of an active posture of women entrepreneurs within a socially constructed gendered environment, allowing for action to be taken in order to deconstruct and counterbalance existing gender dynamics.

Our research has implications for different actors in the economic landscape, including women entrepreneurs themselves, (women's) entrepreneurship support organizations and world political representatives. We underline the importance of work on the gendered selfperceptions of women entrepreneurs, which have a key impact on their perceptions, decisions and actions in terms of networking and entrepreneurship. We also highlight the necessity of changing the existing image of women entrepreneurs as a whole, often considered and 
presented as 'the others' in entrepreneurship research and practice. We finally underline the potential of Facebook and of virtual social networking sites more generally for women's entrepreneurship, in enabling some women entrepreneurs to combine networking with family responsibilities, in supporting and enhancing the development of women's networks and in offering new opportunities for doing business.

\section{Acknowledgments}

The author would like to thank Isabelle Cecchini and Professor Annie Cornet (HC-ULg) for their contributions to the shape of this research project and for their helpful comments on earlier drafts. The research team is grateful for the financial support for this project from the European Social Fund and Minister Marcourt, VicePresident and Minister for the Economy, SMEs, Foreign Trade and New Technologies of the Walloon Government and Vice-President and Minister for Higher Education of the French Community of Belgium.

\section{References}

Ahl, H. (2004), The Scientific Reproduction of Gender Inequality: A Discourse Analysis of Research Texts on Women's Entrepreneurship, Liber, Malmo, Sweden.

Ahl, H. (2006), 'Why research on women entrepreneurs needs new directions', Entrepreneurship Theory and Practice, Vol 30, No 5, pp 595-621.

Aldrich, H. (1989), 'Networking among women entrepreneurs', in Hagan, O., Rivchun, C., and Sexton, D. L., eds, WomenOwned Businesses, Praeger, New York.

Aldrich, H., Reeze, P. R., and Dubini, P. (1989), 'Women on the verge of a breakthrough: networking among entrepreneurs in the United States and Italy', Entrepreneurship and Regional Development, Vol 1, No 4, pp 339-356.

Åndersson, Å., and Evensson, C. (2000), 'The personal networks of women entrepreneurs in the IT trade', doctoral thesis, Karlstad University, Karlstad.

Ashmore, R. D., Deaux, K., and McLaughlin-Volpe, T. (2004), 'An organizing framework for collective identity: articulation and significance of multidimensionality', Psychological Bulletin, Vol 130, No 1, pp 80-114.

Baines, S., and Wheelock, J. (1998), 'Working for each other: gender, the household and micro-business survival and growth', International Small Business Journal, Vol 17, No 1, pp 16-36.

Belcourt, M. L., Burke, R. J., and Lee-Gosselin, H. (1991), The Glass Box: Women Business Owners in Canada, Canadian Advisory Council on the Status of Women, Ottawa.

Blisson, D., and Rana, B. K. (2001), 'The role of entrepreneurial networks: the influence of gender and ethnicity in British SME's', 46th International Council for Small Business Conference, 17-20 June, Taipei, Taiwan.

Buttner, E. H. (1993), 'Female entrepreneurs: how far have they come?' Business Horizons, Vol 36, No 2, pp 59-65.

Buttner, E. H., and Rosen, B. (1988), 'Bank loan officers perceptions of the characteristics of men, women, and successful entrepreneurs', Journal of Business Venturing, Vol 3, No 3, pp 249-258.

Carter, N. M., Brush, C. G., Greene, P. G., Gatewood, E. J., and Hart, M. M. (2003), 'Women entrepreneurs who break through to equity financing: the influence of human, social and financial capital', Venture Capital, Vol 5, No 1, pp 1-28. Chen, W., and Wellman, B. (2009), 'Net and jet', Information, Communication and Society, Vol 12, No 4, pp 525-547.

Constantinidis, C. (2010), 'Représentations sur le genre et réseaux d'affaires chez les femmes entrepreneures', Revue Française de Gestion, Vol 36, No 202, pp 127-143.

Cromie, S., and Birley, S. (1992), 'Networking by female business owners in Northern Ireland', Journal of Business Venturing, Vol 7, No 3, pp 237-251.

de Bruin, A., Brush, C. G., and Welter, F. (2007), 'Advancing a framework for coherent research on women's entrepreneurship', Entrepreneurship Theory and Practice, Vol 31, No 3, pp 323-339.

Doyle, W., and Young, J. D. (2001), 'Entrepreneurial networks in the micro-business sector: examining differences across gender and business stage', Journal of Small Business and Entrepreneurship, Vol 16, No 1, pp 40-55.

Ellemers, N., Kortekaas, P., and Ouwerkerk, J. W. (1999), 'Selfcategorisation, commitment to the group and group self-esteem as related but distinct aspects of social identity', European Journal of Social Psychology, Vol 29, Nos 2-3, pp 371-389.

Ely, R., and Padavic, I. (2007), 'A feminist analysis of organizational research on sex differences', Academy of Management Review, Vol 32, No 4, pp 1121-1143.

Facebook (2010), 'Facebook Press Room', website: http:// www.facebook.com/press/info.php?statistics\#!/press.php (accessed 16 December 2010).

Fenwick, T. J. (2003), Women Entrepreneurs: A Critical Review of the Literature, Department of Educational Policy Studies, University of Alberta, Edmonton, Alberta, Canada.

Gamba, M., and Kleiner, B. H. (2001), 'The old boys' network today', International Journal of Sociology and Social Policy, Vol 21, No 8, pp 101-107.

Hall, D., and Bennett, D. (2000), The Hallmarks for Successful Business, Management Books, Brighton.

Hamouda, A., Henry, C., and Johnston, K. (2003), 'The role of networking in the creation and development of women-led businesses: a study of female entrepreneurs in Ireland', 26th ISBA National Small Firms Policy and Research Conference, 12-14 November, Guildford.

Hampton, A., Cooper, S., and McGowan, P. (2009), 'Female entrepreneurial networks and networking activity in technology-based ventures', International Small Business Journal, Vol 27, No 2, pp 193-214.

Herring, S. C. (2001), Gender and Power in Online Communication, Center for Social Informatics, Indiana University, Bloomington, IN.

Katz, J. A., and Williams, P. M. (1997), 'Gender, self-employment and weak-tie networking through formal organizations', Entrepreneurship and Regional Development: An International Journal, Vol 9, No 3, pp 183-198.

Kergoat, D. (2000), 'Division sexuelle du travail et rapports de sexe', in Hirata, H., Laborie, F., Le Doaré, H., and Senotier, D., eds, Dictionnaire critique du féminisme, PUF, Paris.

Knouse, S. B., and Webb, S. C. (2001), 'Virtual networking for women and minorities', Career Development International, Vol 6, No 4, pp 226-229.

Lambrecht, J., Pirnay, F., Amedodji, P., and Aouni, Z. (2003), Entrepreneuriat féminin en Wallonie: Rapport complet, Université de Liège and K.U. Brussel, Liège, Belgium.

Lewis, K., Kaufman, J., Gonzalez, M., Wimmer, A., and Christakis, N. (2008), 'Tastes, ties, and time: a new social network dataset using Facebook.com', Social Networks, Vol 30, No 4, pp 330-342.

Lewis, P. (2006), 'The quest for invisibility: female entrepreneurs and the masculine norm of entrepreneurship', Gender, Work and Organization, Vol 13, No 5, pp 453-469.

Loane, S. (2006), 'The role of the Internet in the internationalisation of small and medium sized companies', Journal of International Entrepreneurship, Vol 3, No 4, pp 263-277. 
Mankelow, G., Mundie, F., and Thompson, M. J. (2002), 'The role of network by Australian small business owners', 47th International Council for Small Business Conference, 16-19 June, San Juan, Puerto Rico.

Manolova, T. S., Carter, N. M., Manev, I. M., and Gyoshev, B. S. (2007), 'The differential effect of men and women entrepreneurs' human capital and networking on growth expectancies in Bulgaria', Entrepreneurship Theory and Practice, Vol 31, No 3, pp 407-426.

Manolova, T. S., Manev, I. M., Carter, N. M., and Gyoshev, B. S. (2006), 'Breaking the family and friends' circle: predictors of external financing usage among men and women entrepreneurs in a transitional economy', Venture Capital, Vol 8, No 2, pp 109-132.

Moore, D. P. (1990), 'An examination of present research on the female entrepreneur: suggested research strategies for the 1990's', Journal of Business Ethics, Vol 9, No 4/5, pp 275281.

Moore, D. P., and Buttner, E. H. (1997), Women Entrepreneurs: Moving Beyond the Glass Ceiling, Sage, Thousand Oaks, CA

Renzulli, L. A., Aldrich, H., and Moody, J. (2000), 'Family matters: gender, networks, and entrepreneurial outcomes', Social Forces, Vol 79, No 2, pp 523-546.

Ruef, M., Aldrich, H. E., and Carter, N. M. (2003), 'The structure of organizational founding teams: homophily, strong ties, and isolation among U.S. entrepreneurs', American Sociological Review, Vol 68, No 2, pp 195-222.

Schwartz-DuPre, R. L. (2006), 'Women in debate: from virtual to material', Contemporary Argumentation and Debate, Vol 27, pp 106-120.

Smeltzer, L. R., and Fann, G. L. (1989), 'Gender differences in external networks of small business owner/managers', Journal of Small Business Management, Vol 27, No 2, pp 25-32.

St-Cyr, L., de Champlain, O., Boffo, C., and Streliski, M. (2001), Banque de données sur les entrepreneures québécoises, Chaire de Développement et de Relève de la PME, Ecole des HEC, Quebec.

St-Cyr, L., and Gagnon, S. (2004), 'Les entrepreneures québécoises: Taille des entreprises et performance', $7 e$ Congrès International Francophone sur la PME, 27-29 October, Montpellier, France.

Tufekci, Z. (2008), 'Grooming, gossip, Facebook and MySpace', Information, Communication and Society, Vol 11, No 4, pp 544-564.

Veltz, P. (2002), Des lieux et des liens: Le territoire français à l'heure de la mondialisation, Éditions de l'Aube, La Tour d'Aigues, France.

Weiser, E. B. (2000), 'Gender differences in Internet use patterns and Internet application preferences: a two-sample comparison', CyberPsychology and Behavior, Vol 3, No 2, pp 167-178. 